\title{
Thinning of the Horcones inferior debris-covered glacier, derived from five ablation seasons by semi-continuous GNSS geodetic surveys (Mt. Aconcagua, Argentina)
}

\author{
M. Gabriela Lenzano' ${ }^{1}$ Luis Lenzano ${ }^{2}$, Jorge Barón ${ }^{1}$, Esteban Lannutti², \\ Marcelo Durand ${ }^{2}$, Dario Trombotto Liaudat ${ }^{3}$
}

\author{
I Universidad Nacional de Cuyo-CONICET. Ciudad Universitaria, Mendoza, Argentina. \\ mlenzano@mendoza-conicet.gob.ar;jbaron@fing.uncu.edu.ar \\ 2 Departamento de Geomática, Instituto Argentino de Nivología, Glaciología y Ciencias Ambientales, (IANIGLA)-Centro Cientifico \\ Tecnológico (CCT)-CONICET, Avda. Ruiz Leal s/n, Parque Gral. San Martín, Mendoza, Argentina. \\ llenzano@mendoza-conicet.gob.ar; elannutti@mendoza-conicet.gob.ar;mdurand@mendoza-conicet.gob.ar \\ 3 Departamento de Geocriología, Instituto Argentino de Nivología, Glaciología y Ciencias Ambientales, (IANIGLA)-Centro Cientifico \\ Tecnológico (CCT)-CONICET, Avda. Ruiz Leal s/n, Parque Gral. San Martín, Mendoza, Argentina. \\ dtrombot@mendoza-conicet.gob.ar
}

\begin{abstract}
We report on ice movements changes in the Horcones Inferior Glacier (HIG), a major debris-covered glacier located in the southern sector of Mt. Aconcagua, Central Andes of Argentina. The HIG has been characterized by outstanding surge phenomena in the recent past, with the last episode registered in 2003. After a surge episode, the surface becomes highly unstable, with continuous ice degradation. We studied the response of the glacier surface in the post-surge stagnation period, based on six semi-continuous Global Navigation Satellite System (GNSS) stations distributed along the main axis of the glacier. Kinematic GNSS profiles were acquired over the surface, aiming to strengthen the GNSS measurements of elevation change. Our results show a horizontal surface displacement from $0.4 \mathrm{cmd}^{-1}$ to $2.7 \mathrm{cmd}^{-1}$, and a $0.8 \mathrm{cmd}^{-1}$ mean elevation reduction during the 2009-2014 period. GNSS profiles also show a velocity increase, ranging from $-1.1 \mathrm{cmd}^{-1}$ in 2012 to $-1.8 \mathrm{cmd}^{-1}$ in 2013. Changing surface velocities in the HIG may be related to the presence of a thick debris cover, in combination with faster glacier degradation due to thickness loss after the 2003 surge, and glacier-climate interaction.
\end{abstract}

Keywords: GNSS, Debris-covered glacier, Change detection, Mt. Aconcagua.

RESUMEN. Adelgazamiento del glaciar cubierto Horcones Inferior, derivado de mediciones geodésicas mediante el uso de estaciones semicontinuas GNSS, durante un período de cinco estaciones de verano $\left(\mathrm{C}^{\circ}\right.$ Aconcagua, Argentina). En el presente estudio, se muestran los cambios de movimientos superficiales registrados por el Glaciar Horcones Inferior (GHI) el mayor glaciar cubierto localizado en el sector Sur del $\mathrm{C}^{\circ}$ Aconcagua, Andes Centrales de Argentina. El GHI, se ha caracterizado por experimentar fenómenos de surges en el pasado reciente, cuyo último episodio registrado fue en el año 2003. Después de un episodio de surge, la superficie se comienza a suavizar mediante un continuo proceso de degradación del hielo. En este sentido, se ha estudiado la superficie del glaciar en el período de reposo postsurge, colocando seis estaciones semi continuas GNSS, distribuidas a lo largo del eje central del GHI. Además, perfiles cinemáticos GNSS fueron realizados sobre la superficie, con el objetivo de fortalecer y correlacionar las mediciones GNSS en el cambio de elevación. Los resultados muestran un desplazamiento horizontal de la superficie desde $0.4 \mathrm{cmd}^{-1}$ a $2.7 \mathrm{cmd}^{-1}$, y una disminución en el valor de la elevación media de $0.8 \mathrm{cmd}^{-1}$, durante el período 2009 2014. Los perfiles cinemáticos GNSS arrojaron un incremento en la velocidad de decrecimiento en elevación desde $-1.1 \mathrm{cmd}^{-1}$ en 2012, a $-1.8 \mathrm{cmd}^{-1}$ en 2013. Cambios en las velocidades superficiales del GHI pueden estar relacionados con la presencia del espesor de la cubierta de detritos, en combinación con la rápida degradación que sufrió el glaciar después del surge de 2003 y también con la interacción del glaciar con el clima. 


\section{Introduction: Study area and historical re- constructions}

Regional climate changes directly affect cryospheric environments and their hydrological systems (Parry et al., 2007). During the late $20^{\text {th }}$ and early $21^{\text {st }}$ centuries, glaciers around the world have suffered significant recession (IPCC, 2014). Glacier shrinkage in the Central Andes has been accelerating over the last few decades (Leiva et al., 2007; Bown et al., 2008; Lenzano, 2013). This ongoing reduction of icecovered areas is one of the most reliable indicators of climate change (Haeberli, 2005), but in the same way glaciers exhibit a broad range of responses to climate. The speed and magnitude of the response to climate sensitivity of a given glacier depends, among other factors, on its geometry, and can have significant variations (Banerjee and Shankar, 2013). Thus, it is considerably challenging to relate climate change with the variations in the response to climate of individual glaciers. For example, some glaciers may undergo surge phases, which are periods of sudden advance and/or episodes of exceptionally high speed flow, caused by factors that are not necessarily related to climatic changes (Meier and Post, 1969; Kamb, 1985, 1987; Kotlyakov et al., 2004, 2008). Surging glaciers undergo periodic phases of rapid flow between longer intervals of stagnation. Given the rapid and severe changes the system undergoes during surges, it is important to observe both how the surface is affected and how does the mass of the glacier change during the quiescent period. The Central Andes represent an important region for these extreme processes (Espizúa and Bengochea, 1990): surges here are comparable in magnitude to those in the Karakorum and Alaska (Hewitt, 1969).

Because glaciers play a significant role in providing water to arid and semiarid regions, such as western Argentina, and some of them representing hazards to the population, it is crucial to determine and understand the changes affecting glaciers in these regions.

The Horcones Inferior Glacier (HIG) is located at $32^{\circ} 41^{\prime} \mathrm{S}, 69^{\circ} 57^{\prime} \mathrm{W}$, in the southern slopes of Mt. Aconcagua (6,962 $\mathrm{m}$ a.s.l. -highest point in the Americas), Argentina, as shown in figure 1. The total glacierized area is $5.6 \mathrm{~km}^{2}$, and $11 \mathrm{~km}$ of length. The HIG is fed from Superior and Medio Glaciers, which are hanging glaciers on the south face of Mt. Aconcagua. The type of feeding by contribution of snow avalanches makes the HIG comparable to other typical cases of surging glaciers (Hewitt, 1969). Fresh ice from these glaciers incorporates into the reconstituted $\mathrm{HIG}$, which is steadily covered by debris from talus and snow avalanches. Below 4,200 $\mathrm{m}$ a.s.l., the glacier ablates, and the surface presents a large amount of thermokarst and meltwater ponds. Observations near its terminus suggest that HIG has a temperate bed, as Benn and Evans (2007) define these characteristics.

The HIG has experienced surge episodes and extraordinary advances in the recent past. The 1984
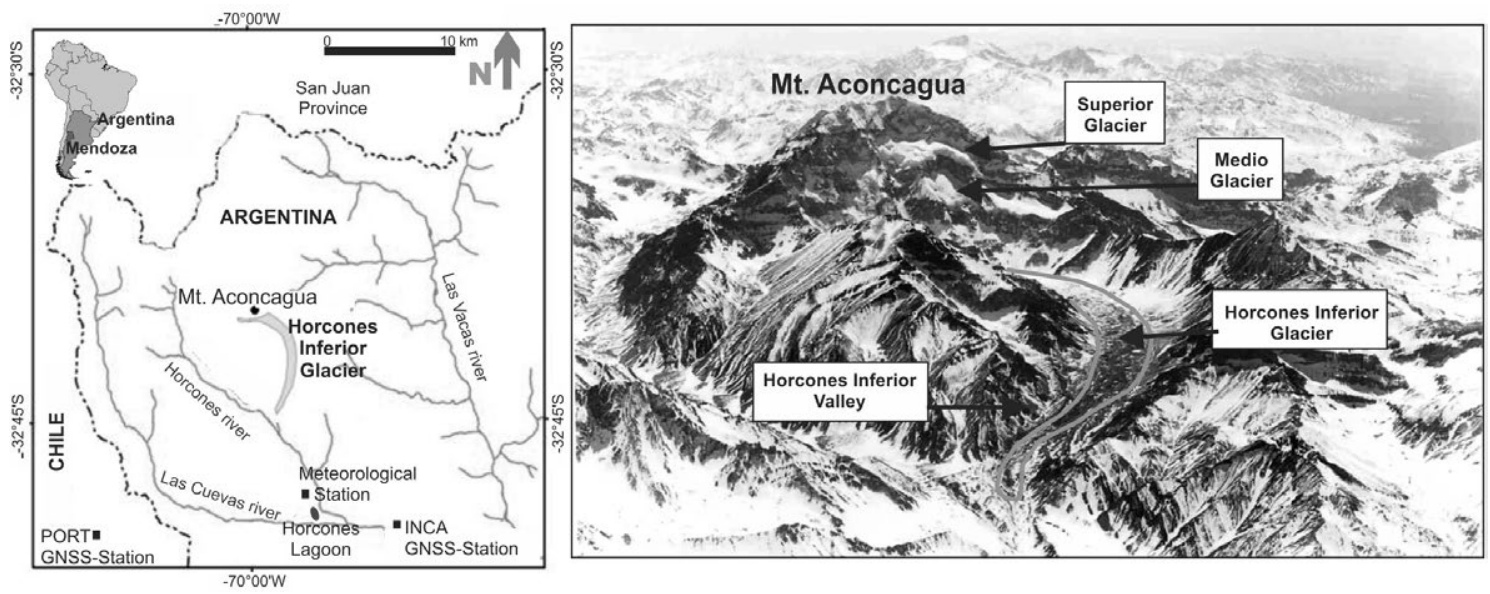

FIG. 1. Location map of the study area. A. Location in Argentina, and the Cordillera de Los Andes, South America; B. Oblique view of the study area. Mt. Aconcagua, the Horcones Inferior Glacier and the south wall of Aconcagua are shown. 
surge was explained using a model of extensional deformation and listric faults in the ice (Milana, 2007). During surges, ice breaks over the entire glacier into large irregular ice blocks, which generally dip more than $50^{\circ}$; they are oriented almost perpendicularly to the flow (south) direction and are inclined against the flow direction. These features render the surface structure of the glacier chaotic. After the surge, the surface slowly becomes less chaotic as the ice degrades, and the ablation rate decreases as the debris cover thickness increases toward the front. The last two surges in 1984 and 2003 were studied using satellite imagery (Unger et al., 2001; Espizúa at WGMS, 2008). The interaction of the surges with thermokarst processes was also investigated by Lenzano et al. (2012). These authors also carried out studies to monitor the ice mass balance using DTM's and GNSS technologies (Lenzano et al., 2013).Velocities up to $35 \mathrm{~m}^{-1}$ were recorded by Leiva (2006) at the glacier terminus in the summer of 2004-2005.

As well as recording and interpreting the changes in the glacier, the presence of surges has hazard-related implications and thus, the study of this behavior is important (Kääb et al., 2005). Improvements made in methods provide opportunities to monitor surface movements precisely and accurately at temporal frequencies necessary for study glaciers motion. The development of GPS technology has proven to be a useful tool for obtaining precise information of the movement of glaciers, in several other regions (Eiken et al., 1997; Tregoning et al., 1999; Lidberg et al., 2006, Copland et al., 2009), and the deployment of continuous or semi-continuous GNSS stations on glacier surfaces has provided high temporal detail of their response.

The work presented here provides a five-year survey of the motion of the HIG. The main goal of the present study was to assess the magnitude of displacement and velocity and elevation changes in the HIG from the time of the 2003 surge through the 2009-2014 period of stagnation. Surface movement was recorded by six semi-continuous GNSS survey stations placed in the ablation zone during the warm seasons between 2009 and 2014 to have a better understanding of HIG behavior in that region. Kinematic GNSS profile in the same area was also acquired during ablation seasons over the 2011-2013 period to contribute with the glacier motion.

\section{Field activities and methods}

\subsection{Semi-continuous GNSS survey stations}

To obtain a continuous time series of the summertime surface velocity (Sunil et al., 2007), five semi-continuous GNSS stations were installed along the centerline of the glacier (Table 1). A sixth station (HIS6) was also placed at 4,037 $\mathrm{m}$ a.s.l. in the 2013-2014 season, but due to breakage of the controller only 4 days of data were recorded. The system was powered by lead acid batteries, charged by two $38 \mathrm{~W}$ solar panels. The receivers with the supporting electronic systems were protected by a waterproof enclosure in a box, with a bolt on the top that hold the antenna (Fig. 2A-B). The antennas

TABLE 1. OCCUPATION TIMES OF GPS STATIONS.

\begin{tabular}{cccccc}
\hline Station & Receiver & Period & Start date & End date & Total days \\
\hline \multirow{2}{*}{ HIS1 } & Tech-Geo & 2009 & $1-29-2009$ & $3-14-2009$ & 45 \\
& Tech-Geo & $2009-2010$ & $12-11-2009$ & $2-11-2010$ & 68 \\
& Tech-Geo & $2010-2011$ & $12-30-2010$ & $1-24-2011$ & 26 \\
& Tech-Geo & 2012 & $2-10-2012$ & $4-11-2012$ & 61 \\
& Trimble NetRS & $2013-2014$ & $17-12-2013$ & $5-05-2014$ & 137 \\
HIS2 & Trimble 5700 & 2012 & $1-04-2012$ & $5-09-2012$ & 126 \\
HIS3 & Trimble 5700 & 2012 & $1-05-2012$ & $5-09-2012$ & 125 \\
& Trimble NetRS & $2013-2014$ & $12-17-2013$ & $1-29-2014$ & 40 \\
HIS4 & Trimble 5700 & $2013-2014$ & $12-18-2013$ & $4-16-2014$ & 119 \\
\hline
\end{tabular}




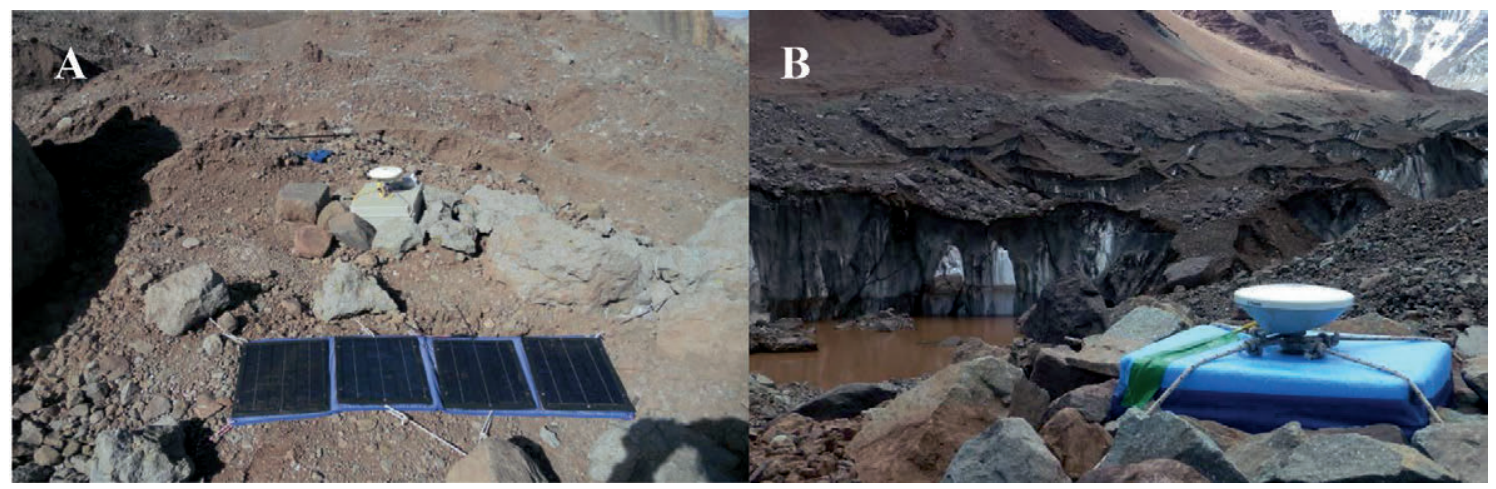

FIG. 2. A. HIS1 GNSS station with the antenna mounted on a box platform on the glacier; B. HIS4 station on the HIG surface.

were oriented to the magnetic north in the field, and thereby correcting by magnetic declination. In order to locate every year the same locations, stations were materialized by rods on the glacier surface.

A Tech-Geo L1 single-frequency GNSS receiver was used for the HIS1 station in the 2009-2012 seasons (Fig. 2A). The HIS1 station (3,596 m a.s.1.) was operated for five summer seasons (Table 1). In the first period (2009-2010), the station operated for 45 days. Between December 2010 and January 2011, technical difficulties resulted in only 26 days of recorded data. Thus, on May 2011, we reoccupied the site with 48 hs. measurements to obtain an estimated position of the HIS1 station during a long period. During the summer of 2012 the station collected data for 61 days. The station was visited occasionally to correct antenna misalignment due to the movements of the glacier surface. Vertical errors were introduced by the displacement and elevation changes of the moving ice but were small enough to be disregarded, particularly considering that single-frequency GNSS equipment was used (Wang, 2003). A Trimble NetRS (dual-frequency) was placed at this station for the 2013-2014 period to replace the Tech-Geo single frequency receiver. Two more stations (Trimble 5700 dual-frequency receivers), HIS2 and HIS3, were placed at higher elevations to collect complementary information in the summer of 2012 (Fig. 2B). During the summer of 2013-2014, further measurements were carried out on the glacier surface, adding three more stations. Figure 3 shows the location of the stations in the HIG.

The data was processed with Bernese 5.0 software (Dach et al., 2007). GNSS carrier phase data was processed with precise ephemeris from the Inter- national GPS Service (IGS). Data was referenced to the Posicionamiento Geodésico Argentino 98 (POSGAR98) reference frame. In order to process the GNSS data, the sites were linked and processed in parallel to two continuous GNSS stations: Portillo (PORT, $32^{\circ} 50^{\prime} \mathrm{S} ; 7^{\circ} 07^{\prime} \mathrm{W}$ ), located in Libertadores, Chile (15 km away from HIG), and Puente del Inca (INCA, 32 $49^{\prime} \mathrm{S} ; 69^{\circ} 54^{\prime} \mathrm{W}$ ), located approximately $10 \mathrm{~km}$ away from HIG (Fig. 1). Because the HIS1 station used L1 frequency and the baseline was shorter than $20 \mathrm{~km}$, the SIGMA algorithm was used to solve ambiguities. The dual frequency HIS1, HIS2, HIS3, HIS4, HIS5 and HIS6 stations used the QIF algorithm to solve ambiguities. In all cases, the solutions were fixed at the $95 \%$ confidence level. Table 2 shows the mean RMS (root mean square) error achieved for each period of the GNSS data. These errors are mathematically appropriate and are a lower order of magnitude than the movement of the glacier, which is the variable to be measured.

\subsection{Kinematic data}

An axial profile in the ablation zone, across the HIS1, HIS2, and HIS3 sites was surveyed to determine elevation changes of the surface in January 2012, May 2012, and March 2013 respectively (A-B, Fig. 3). For every season, the profiles were measured at the same horizontal coordinates (Lat. and Lon.), replicating the profile trajectory by GNSS kinematic surveys. During the first two seasons, there was a discontinuity in the trend of data due a large depression similar to a thermokarst that interrupts the central part of the glacier (see Fig. 4). Thus, this area cannot be taken into account because it was not 


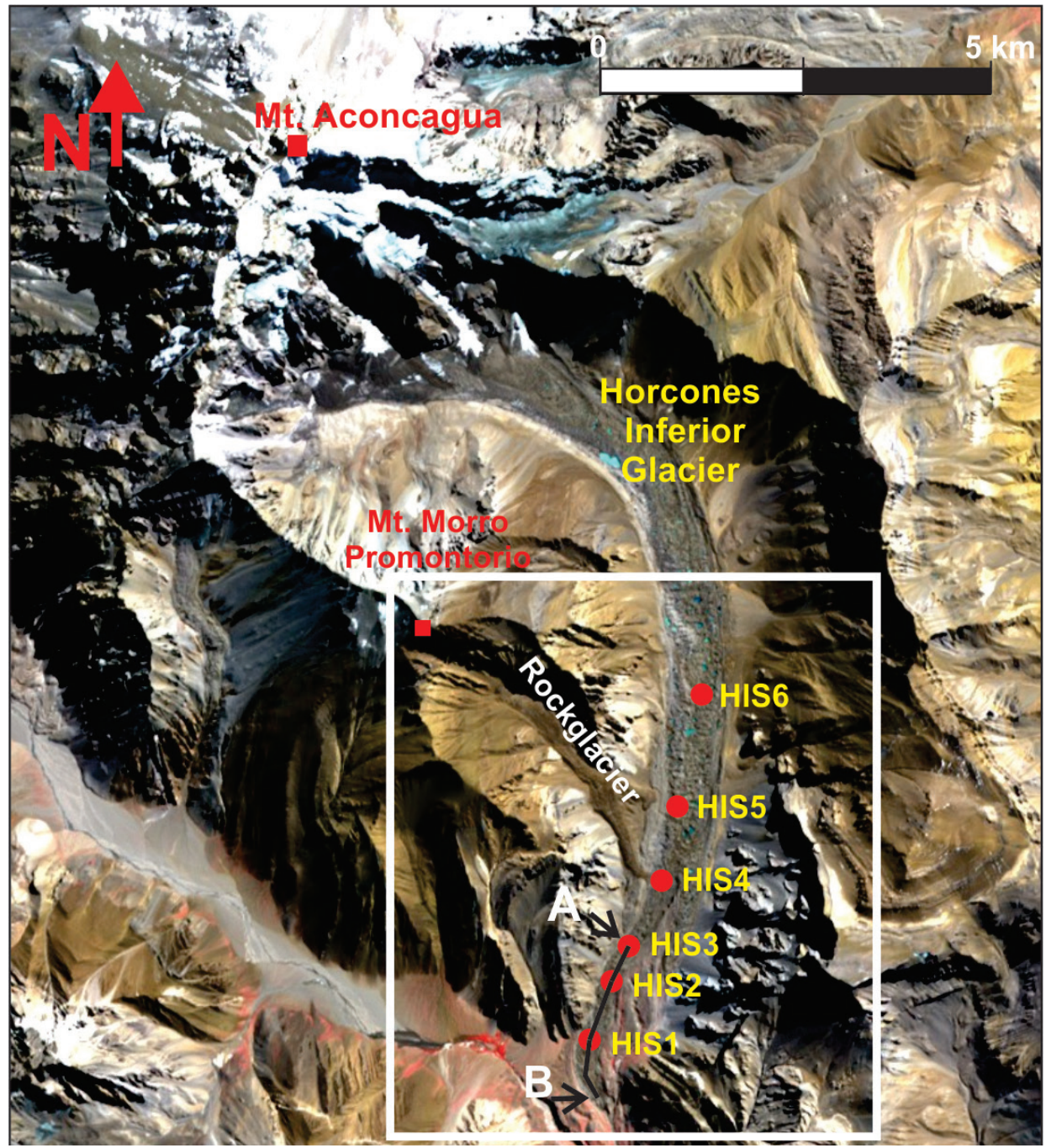

FIG. 3. Map indicating the locations of the semi-continuous GNSS stations in the HIG. A-B is the location of the GNSS profiles across the glacier surface.

possible to continue the line of the axial profile. By March 2013, the surface had smoothed in this area and the profile A-B was continuous. The survey area covered the lowermost kilometer approximately of the HIG. A dual-frequency Trimble 5700 with a data acquisition rate of 5 seconds was used.

The kinematic profiles were processed using RtkLib open-source software (Wiśniewski et al., 2013). The kinematic sites were linked to the INCA GNSS continuous station. Precise ephemerides were used to improve accuracy in the positions. In all the profiles, ambiguities were fixed at the $95 \%$ confidence level. The mean accuracy for the profiles was $0.05 \mathrm{~m}$.

\section{Results: glacier changes detection}

\subsection{Seasonal ice movements and velocities}

\subsubsection{HIS1 GPS station}

Simple terrain observations have suggested that three years after the 2003 surge, the glacier showed a much lower velocity, and may have reached a quiescent stage. Its topographic relief, however, continues to change every year due to continuous ice degradation. In the first season, the GNSS-measured surface changed between January and March of 2009. The observed horizontal changes were $0.51 \mathrm{~m}$ 
TABLE 2. ACCURACY OF DATA PROCESSING.

\begin{tabular}{cccc}
\hline Season & RMS $_{\varphi}(\mathbf{m})$ & $\mathbf{R M S}_{\lambda}(\mathbf{m})$ & $\mathbf{R M S}_{\mathbf{u}}(\mathbf{m})$ \\
\hline HIS1 2009 & \pm 0.004 & \pm 0.003 & \pm 0.009 \\
HIS1 2010 & \pm 0.002 & \pm 0.003 & \pm 0.009 \\
HIS1 2011 & \pm 0.006 & \pm 0.008 & \pm 0.010 \\
HIS1 2012 & \pm 0.005 & \pm 0.006 & \pm 0.011 \\
HIS1 2014 & \pm 0.005 & \pm 0.007 & \pm 0.015 \\
HIS2 2012 & \pm 0.003 & \pm 0.002 & \pm 0.004 \\
HIS3 2012 & \pm 0.003 & \pm 0.003 & \pm 0.004 \\
HIS3 2014 & \pm 0.009 & \pm 0.010 & \pm 0.014 \\
HIS4 2014 & \pm 0.007 & \pm 0.009 & \pm 0.019 \\
HIS5 2014 & \pm 0.005 & \pm 0.006 & \pm 0.012 \\
HIS6 2014 & \pm 0.004 & \pm 0.003 & \pm 0.009 \\
\hline
\end{tabular}

to the southwest (SW) (towards the terminus of the glacier), whereas vertically, the glacier surface decreased by $0.48 \mathrm{~m}$. In addition, a decrease of $1.1 \mathrm{~m}$ was measured between the removal of the station in March 2009 and its reinstallation in December 2009. Furthermore, the station moved 0.73 m horizontally to the SW and decreased vertically $1.40 \mathrm{~m}$ between December 2009 and February 2010. In December 2010, during the third season, a change in altitude of $-0.35 \mathrm{~m}$ and a horizontal shift of $0.11 \mathrm{~m}$ to the
SW was measured. The 2011 data was limited due to technical difficulties within the station. In May 2011 the position was surveyed again, and the elevation change was similar to the previous years. During the winter, before the station reinstallation in February 2012, the surface elevation decreased by $1.62 \mathrm{~m}$. Between February - April 2012 the station moved $0.33 \mathrm{~m}$ to the SW and decreased $0.51 \mathrm{~m}$ in altitude. In the last measured season, from December 2013 to April 2014, the station moved $0.46 \mathrm{~m}$ to the SW and decreased vertically $0.78 \mathrm{~m}$ in 137 days. Figure 4 shows the elevation changes and the Height velocity $\left(\mathrm{V}_{\mathrm{H}}\right)$ as a function of time over the five seasons. These results suggest that HIG experiences some degree of variation in ice motion, where the decreasing rate of surface elevation was roughly similar for all periods, except for 2009-2010.

Figure 5 shows the daily rate of the HIS1 station horizontal position changes during the five seasons. The data displays horizontal surface displacements that are similar for the five periods, except for the 2009-2010 season. The mean surface velocities for HIS1 are listed in Table 3, where the accuracy and also the surface movement's direction are shown. The $\mathrm{V}_{\mathrm{S}}$ (Surface velocity) values estimated during the 2009 and 2009-2010 field seasons were similar, but the motion rate was reduced by approximately $50 \%$ in the following seasons, indicating that the glacier was slowing down and reducing the advance rate towards the terminus. The $\mathrm{V}_{\mathrm{H}}$ represents a spatial

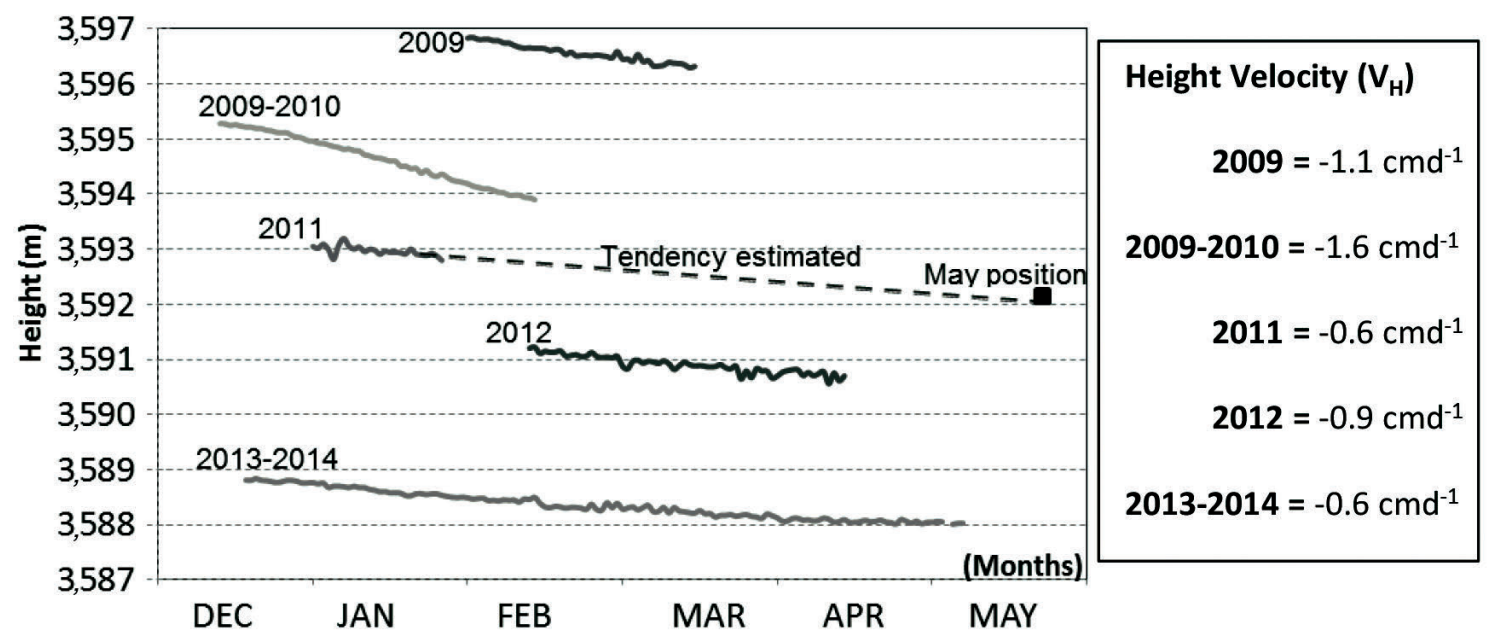

FIG. 4. Elevation changes and Height velocity of the HIS1 station over five field seasons (2009, 2010, 2011, 2012, 2013-2014). Due to interruption of the measurements in 2011, the dashed line shows the estimated glacier surface position. 


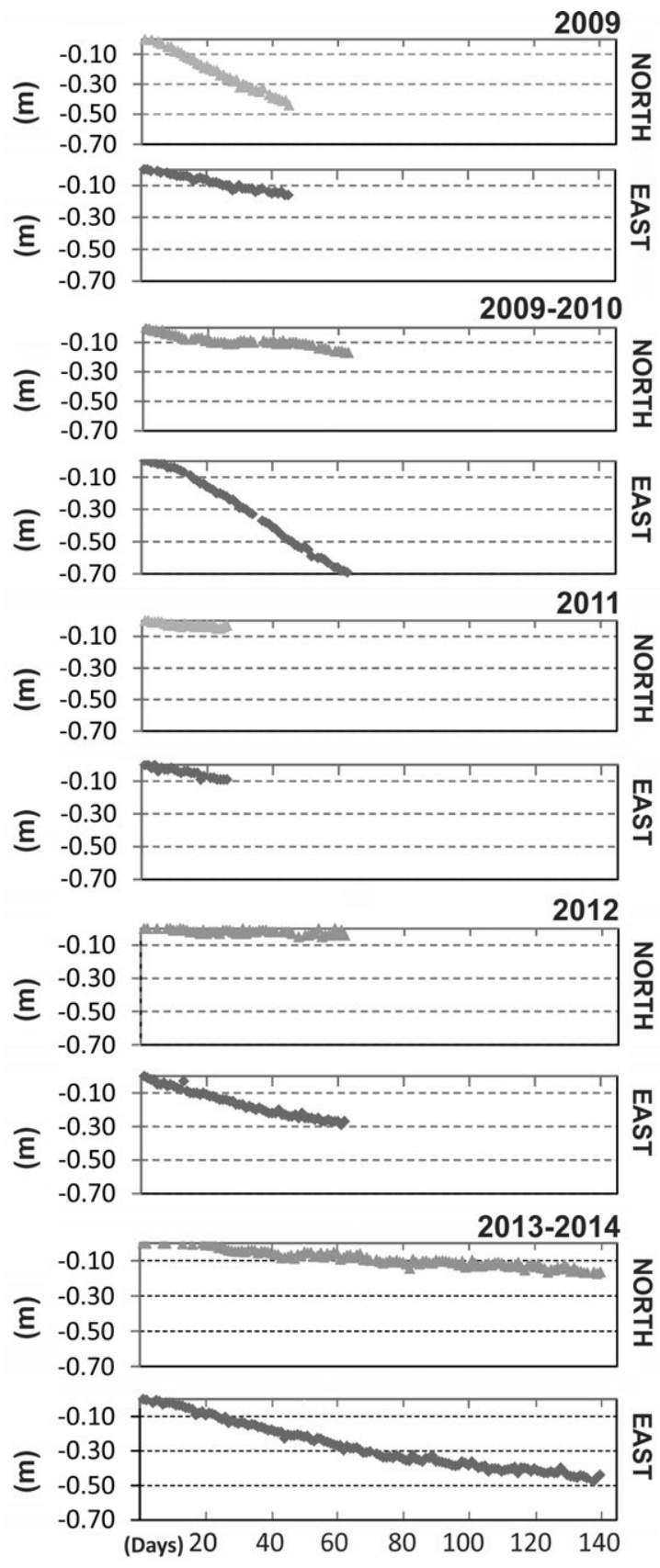

FIG. 5. Displacement changes of the HIS1 station for the North and East component over the five field campaigns.

pattern of glacier movement. The lowest velocity, $-0.6 \mathrm{cmd}^{-1}$, and the highest one, $-1.6 \mathrm{cmd}^{-1}$, were observed in the 2013-2014 and 2009-2010 field seasons respectively, with an average velocity of $-0.96 \mathrm{cmd}^{-1}$ for the whole $2009-2014$ period. The seasonal $\mathrm{V}_{\mathrm{H}}$ changes showed an interesting pattern in the 2009-2010 season, due to an increase of approximately $45 \%$ in the rate of diminishing elevation change. From December 2010 onwards, the altitude changes began to stabilize and are more constant values in later field seasons.

\subsubsection{HIS2, HIS3, HIS4, HIS5 GPS stations}

The HIS2, HIS3, HIS4, HIS5 and HIS6 stations helped to further improve the understanding of the continuous glacier thinning processes using daily GNSS phase observations. These stations, located above HIS1, were aligned along the central flowline of the glacier between 3,625 $\mathrm{m}$ a.s.1. and 3,956 $\mathrm{m}$ a.s.l. (Fig. 3). The goal here was to cover the "new" area (terminus of HIG) after the 2003-2007 surge by analyzing the response in HIS1, HIS2 and HIS3, and the "old" area that HIG had historically occupied before the surge event, as registered by HIS4, HIS5 and HIS6 stations.

The results of the HIS3 and HIS2 stations in 2012 show similar values in the surface displacements (Fig 6). This agrees well with the sites being separated less than $100 \mathrm{~m}$, and the swifter advance can be explained due to the location of both stations in the outer margin before the glacier exits the homonyms valley, where velocity is expected to be lower due to friction. In mid-April, a storm caused an interruption in data collection (Fig. 6), but the stations resumed normal operation after one week. Table 3 shows the mean surface velocity and the direction of movement's surface of HIS2, HIS3, HIS4, HIS5 and HIS6 stations. HIS2 shows a large displacement rate of $\sim 0.8 \mathrm{~m}$ towards the terminus, and an additional descent of $0.5 \mathrm{~m}$, with mean $\mathrm{V}_{\mathrm{S}}=0.7 \mathrm{cmd}^{-1}$ and $\mathrm{V}_{\mathrm{H}}=-0.6 \mathrm{cmd}^{-1}$. Similarly, HIS3 advanced $0.7 \mathrm{~m}$ and descended $0.6 \mathrm{~m}$, with mean velocities of $\mathrm{V}_{\mathrm{S}}=0.6 \mathrm{cmd}^{-1}$ and $\mathrm{V}_{\mathrm{H}}=-0.7 \mathrm{cmd}^{-1}$. HIS2 GPS station was not measured in the following years because the location was close to HIS3. In the 2013-2014 season, HIS3 was set up again but for technical reasons stopped working 44 days after initial operation. The results show a mean horizontal velocity of $\mathrm{V}_{\mathrm{S}}=0.1 \mathrm{cmd}^{-1}$, and $\mathrm{V}_{\mathrm{H}}=-0.4 \mathrm{cmd}^{-1}$ for this period. Comparing this location with the previous results, the velocities show a reduction in the glacier thinning process over time, which in turn is in agreement with the results of HIS1 station for the same period although the velocity in elevation change is quite lower than HIS3. 
TABLE 3. MEAN SURFACE AND ELEVATION VELOCITIES ATE THE GNSS STATIONS.

\begin{tabular}{ccccccc}
\hline Station & Period & $\mathbf{V}_{\mathbf{S}}\left(\mathbf{c m d}^{-\mathbf{1}}\right)$ & $\boldsymbol{\sigma}_{\mathbf{S}}$ & $\mathbf{V}_{\mathbf{S}}$ Direction & $\mathbf{V}_{\mathbf{H}}\left(\mathbf{c m d}^{-\mathbf{1}}\right)$ & $\boldsymbol{\sigma}_{\mathbf{H}}$ \\
\hline HIS1 & 2009 & 0.9 & \pm 0.2 & South-west & -1.1 & \pm 0.4 \\
& $2009-2010$ & 1.1 & \pm 0.3 & South-west & -1.6 & \pm 0.7 \\
& $2010-2011$ & 0.4 & \pm 0.1 & South-west & -0.6 & \pm 0.1 \\
& 2012 & 0.5 & \pm 0.1 & South-west & -0.9 & \pm 0.4 \\
& $2013-2014$ & 0.4 & \pm 0.1 & South-west & -0.6 & \pm 0.1 \\
HIS2 & 2012 & 0.7 & \pm 0.1 & South-west & -0.6 & \pm 0.2 \\
HIS3 & 2012 & 0.6 & \pm 0.1 & South-west & -0.7 & \pm 0.3 \\
& $2013-2014$ & 0.1 & \pm 0.1 & South-west & -0.3 & \pm 0.3 \\
HIS4 & $2013-2014$ & 2.7 & \pm 0.3 & South-east & -0.5 & \pm 0.3 \\
HIS5 & $2013-2014$ & 1.0 & \pm 0.5 & South-west & -0.8 & \pm 0.4 \\
\hline
\end{tabular}
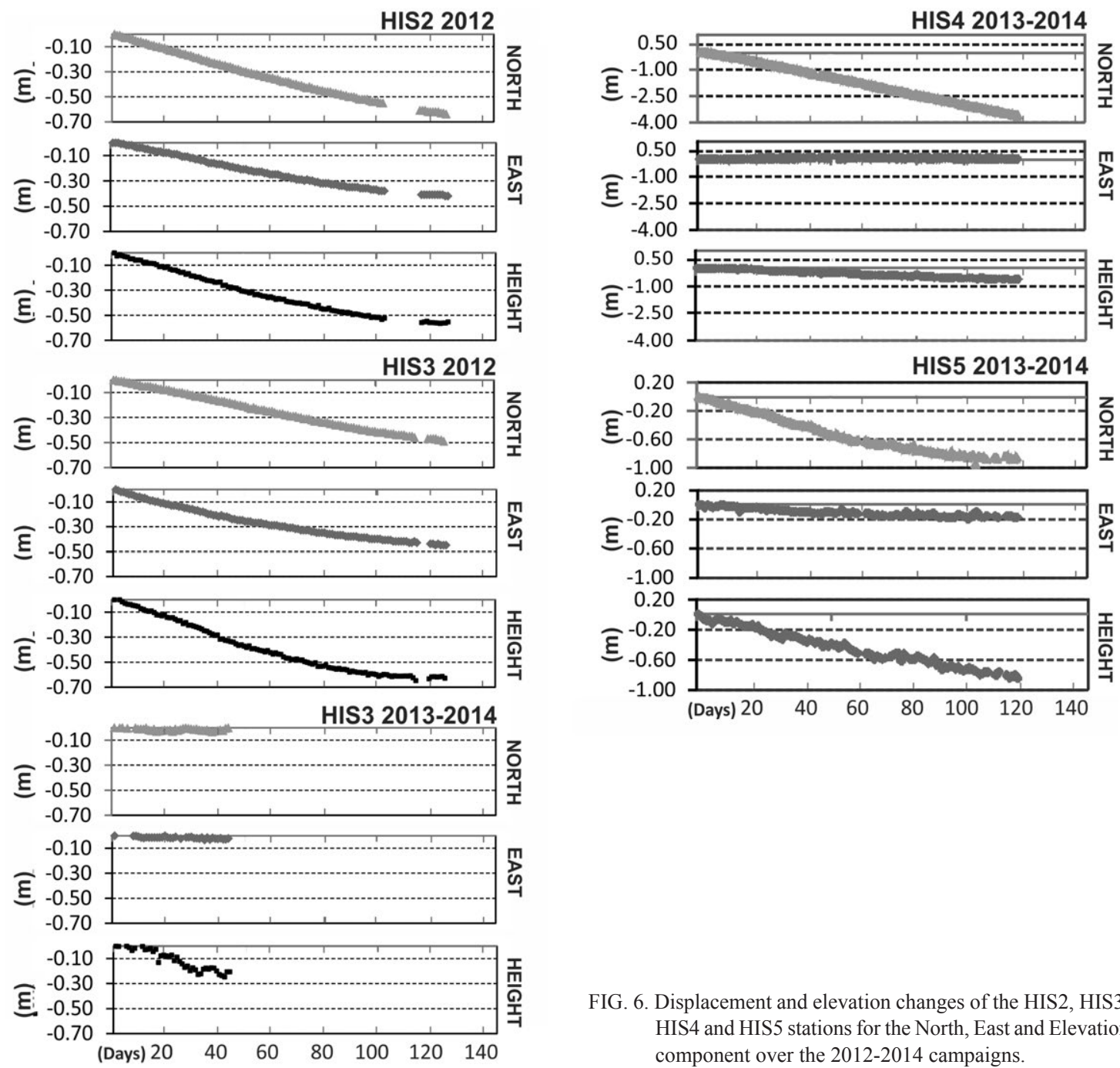

FIG. 6. Displacement and elevation changes of the HIS2, HIS3, HIS4 and HIS5 stations for the North, East and Elevation component over the 2012-2014 campaigns. 
HIS4 and HIS5 stations provided information for a single season for the medium and upper portion of the HIG. HIS4 was placed to the east and close to a rock glacier located in the southeast slope of Mt. Morro Promontorio (Fig. 3). The horizontal displacement of HIS4 station may have been influenced by the rock glacier flow and could have caused a horizontal motion of $3.6 \mathrm{~m}$ in the South component and $0.2 \mathrm{~m}$ in the East direction, which were monitored for a span of 117 days. Mean velocities of $\mathrm{V}_{\mathrm{S}}=2.7 \mathrm{cmd}^{-1}$ and $\mathrm{V}_{\mathrm{H}}=-0.5 \mathrm{cmd}^{-1}$ support this presumption. HIS5 yielded displacement values of $0.9 \mathrm{~m}$ in southwest direction, with average $\mathrm{V}_{\mathrm{S}}=1.0 \mathrm{cmd}^{-1}$ and $\mathrm{V}_{\mathrm{H}}=-0.8$ $\mathrm{cmd}^{-1}$.Unfortunately, the highest HIS6 station ceased operating after 5 days due to an electrical problem in the microcontroller. Although the data is not sufficient for comparison with the other stations, data was nevertheless processed, yielding a velocity of $\mathrm{V}_{\mathrm{S}}=1.9 \mathrm{cmd}^{-1}$ and a decrease in elevation of $\mathrm{V}_{\mathrm{H}}=-0.5$ $\mathrm{cmd}^{-1}$. The results in these stations are interpreted as evidence of ice degradation processes in the HIG that influenced the response of surface velocities and elevation change.

\subsection{Surface elevation changes by axial profiles}

The inclusion of axial profiles allowed for the assessment of altimetry changes in a continuous line, coinciding with the locations of the GNSS stations. The results show a dramatic movement and a surface elevation decrease that is evidence of a glacier thinning from January 2012 until May 2013 (Fig. 7). At lower elevations, the terminus of the glacier is exposed to higher temperatures, which can lead to major degradation processes. Therefore, the discontinuity in the data between $450 \mathrm{~m}$ and $700 \mathrm{~m}$ downslope from HIS3 may be related to the low altitude (3,500 $\mathrm{m}$ a.s.1.) that HIG reached after the 2003 surge. Table 4 shows the mean estimates of elevation change as well as the standard deviation and the seasonal mean velocity between January and May 2012. The elevation differences over the profiles show a mean of $-1.4 \mathrm{~m}$ in 127 days, and the mean velocity was $-1.1 \mathrm{~cm}^{-1}$. In March 2013, this section was finally profiled so the older profiles were connected. The elevation differences between May 2012 and March 2013 yielded a mean elevation change of $-5.2 \mathrm{~m}$, and a mean $\mathrm{V}_{\mathrm{H}}=-1.8 \mathrm{cmd}^{-1}$ over the 305-day period.

\section{Discussion}

Horcones Inferior is a highly unstable glacier, with diminishing ice volume recorded for the 2009-2014 period. Post-surge, the glacier entered a quiescent period of little movement and intense melting. The surface showed an increase in the number of thermokarst features (Lenzano et al., 2012), such as rapidly size- and form-changing depressions and supraglacial ponds. The surge surface topography became less chaotic and smoother.

The results show that the glacier slowed down after the 2003-2007 surge, with a noticeable decline in the ice surface velocities. A mean value of $\mathrm{V}_{\mathrm{S}}=0.84 \mathrm{cmd}^{-1}$ recorded at the GNSS sites, and an accompanying mean decrease in elevation of $0.77 \mathrm{cmd}^{-1}$ in 2009-2014 period were found. The comparison of the results obtained for 2012 and 2013-2014 lead to the conclusion that the elevation changes were different depending on which GNSS station was

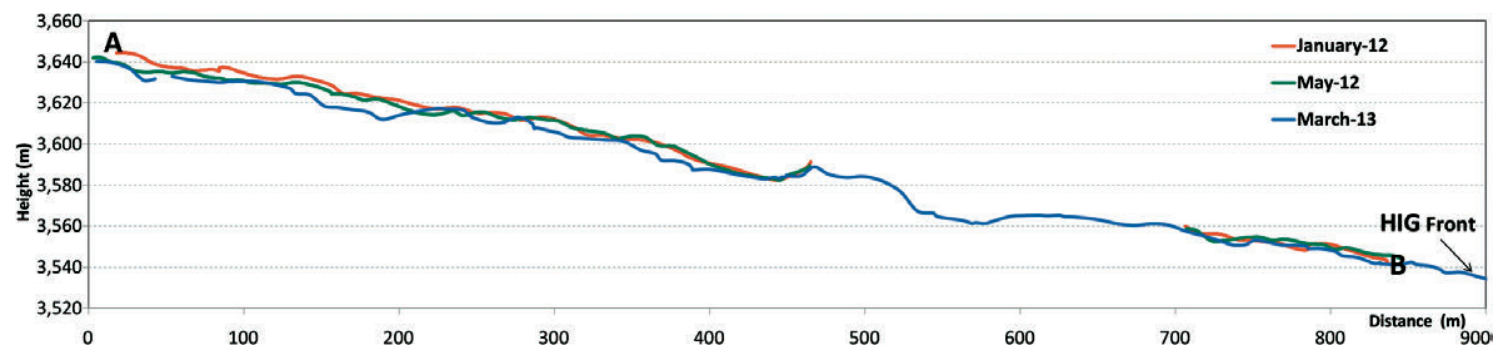

FIG. 7. Axial profiles (A-B) taken on the glacier surface. Each profile was visited three times: January 2012 (black line), May 2012 (dark grey line) and March 2013 (light grey line). 
TABLE 4. MEAN ELEVATION CHANGE $(\Delta H)$, MEAN HEIGHT VELOCITY AND STANDARD DEVIATION FOR THE GLACIER SURFACE PROFILES.

\begin{tabular}{cccc}
\hline Period & $\begin{array}{c}\text { Mean } \\
\boldsymbol{\Delta H}(\mathbf{m})\end{array}$ & $\begin{array}{c}\mathbf{V}_{\mathbf{H}} \\
\left(\mathbf{c m d}^{-1}\right)\end{array}$ & $\begin{array}{c}\boldsymbol{\sigma}_{\mathbf{H}} \\
(\mathbf{m})\end{array}$ \\
\hline January 2012-May 2012 & -1.4 & -1.1 & 0.04 \\
May 2012-March 2013 & -5.2 & -1.8 & 0.06 \\
\hline
\end{tabular}

to be considered. The lowermost station HIS1 at $3,596 \mathrm{~m}$ a.s.l. presented higher rates of elevation change than HIS2 (3,625 m a.s.1.) and HIS3 (3,643 m a.s.1.). The HIS1 station decreased an average of $-2.7 \mathrm{ma}^{-1}$, and HIS3 decreased by $-1.8 \mathrm{ma}^{-1}$ during 2012-2014. However, in 2013-2014 the elevation change showed a lower thinning rate of $\sim 30-60 \%$ compared to the previous year. The new, uppermost stations placed (HIS4 and HIS5) yielded variable results in elevation values, where the highest correspond to HIS5 (3,956 $\mathrm{m}$ a.s.1.). Surface velocities varied between $0.1 \mathrm{cmd}^{-1}$ to $1.0 \mathrm{cmd}^{-1}$ for HIS1, HIS2, HIS3 and HIS5 sites, where the HIS4 shows the highest value of $2.7 \mathrm{cmd}^{-1}$, which may be attributed to the influence of the rock glacier from the side slope of HIG (Fig. 3). Additionally, the axial profiles reinforce the results found by the GNSS surveys, where a mean decrease of $1.4 \mathrm{cmd}^{-1}$ during January 2012 and $4.0 \mathrm{~m}^{-1}$ in March 2013 was recorded.

Beyond glacier response to changing climate conditions, glacier topographic factors (e.g., aspect, altitude, slope, morphology) will influence glacial dynamics (Wang et al., 2011). In the case of debriscovered glaciers, the influence of the debris cover must be deeply considered. The analysis reveals that glaciers with extensive debris cover have a qualitative difference in their response to a warming climate as compared with bare ice glaciers (Banerjee and Shankar, 2013). Depending on its thickness, the debris cover might enhance or alternatively hamper glacier ablation (Mihalcea et al., 2006; Benn and Evans 2010). At similar latitudes and elevation, but in the Northern Hemisphere, Mihalcea et al. (2006) found ablation rates that varied between 3 to $6 \mathrm{cmd}^{-1}$ with a debris layer of $18 \mathrm{~cm}$ to $0 \mathrm{~cm}$ thickness for the debris-covered Baltoro glacier in the Karakoram (4,178 m a.s.l., $35^{\circ} \mathrm{N}$ ) with GNSS surveys. In the Bagrot Valley (Karakorum, $36^{\circ} \mathrm{N}$ ), the lowest ablation rates were $\sim 2.3 \mathrm{cmd}^{-1}$, with a debris cover thickness averaging
$37.5 \mathrm{~cm}$, between 2,500 $\mathrm{m}$ a.s.l. to $3,350 \mathrm{~m}$ a.s.l. (Mayer et al., 2010).

Elevation changes in the HIG for the present study period $\left(\mathrm{V}_{\mathrm{H}}=-0.77 \mathrm{cmd}^{-1}\right)$, yielded lower values than the aforementioned investigations. These findings can be attributed to diverse factors, being bedrock topography and varying climate conditions in different geographic regions two of the most important ones. In the first place, HIG glacier is located at slightly lower latitude $\left(32^{\circ} 41^{\prime} \mathrm{S}\right)$ and similar elevation (3,500 m-4,400 m a.s.1.), both of which should enhance ablation compared to the Baltoro glacier or the Bagrot Valley. HIG has nevertheless a S-SE orientation and furthermore, the Horcones Inferior valley is rather narrow, the glacier being surrounded by steep slopes exceeding 5,000 $\mathrm{m}$ a.s.1. to $6,962 \mathrm{~m}$ a.s.l. (Summit of $\mathrm{C}^{\circ}$ Aconcagua). In order to have a better notion of incoming solar radiation in the valley, we calculated the average spatial distribution of potential insolation on the glacier surface (Gómez-Tagle Chávez and Chávez Huerta, 2004), using the SRTM (Shuttle Radar Topography Mission) digital model, (pixel resolution $=30 \mathrm{~m}$ ), and the solar coordinates from December to March of 2009-2014 period. The results showed that the surface of HIG receives an average of merely five hours of sunlight per day and as a consequence, the effect of ice degradation can be mitigated. Furthermore, it adds that the debris cover has an average thickness between 0.20 $\mathrm{m}$ and $0.50 \mathrm{~m}$ in the area where the GNSS sites were placed, which may additionally hamper the degradation processes.

On the other hand, in order to correlate the glacier thinning retrieved in this study and local climate conditions, daily temperature records from the Horcones meteorological station $(2,800 \mathrm{~m}$ a.s.l) were analyzed. This station is placed in the proximity of the Laguna de Horcones, $5 \mathrm{~km}$ south of HIG (Fig. 1). Figure 8A shows the monthly mean, maximum and minimum temperatures for the winter (cold) season (June, July, August) over the 2001-2013 period. The data shows a slightly cooling trend over the 14-years period, although the maximum winter temperatures have increased since 2009. Nevertheless, if the results of the lowermost GNSS survey station HIS1 site are analyzed, (which has the longest available data record, 2009-2014), elevation changes increase in the 2009-2010 season, when the highest rates occur $\left(\sim 50 \%\right.$ in $\mathrm{V}_{\mathrm{H}}$, Fig. 4). Therefore, the warm (summer) months (December, 

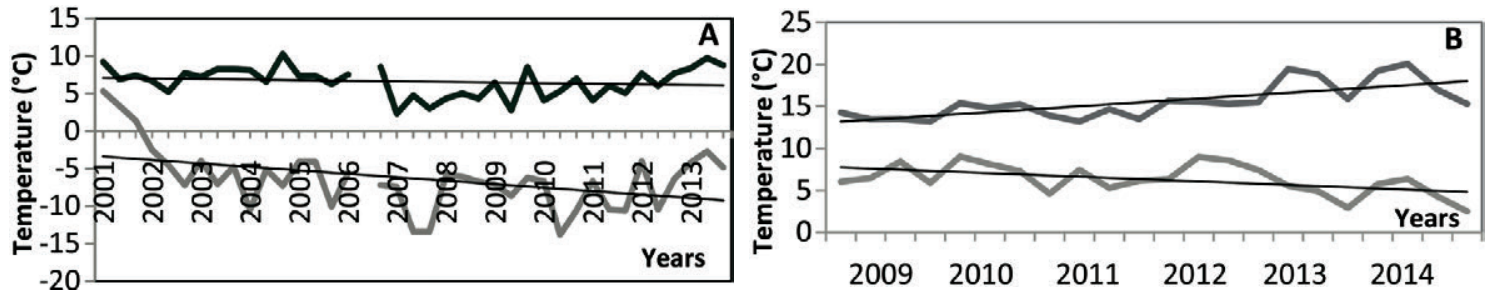

FIG. 8. A. Max (black line) and min (grey line) temperature during the cold season (June, July, August) over the 2001-2013 period; B. Max (black line) and min (grey line) temperature during the warm season (December, January, February and March) over the 2009-2014 period.

January, February and March) over the 2009-2014 period of the Horcones weather station time series were examined (Fig. 8B), and a significant increase in the maximum temperature values is observed, as well as in the minimum temperatures of January and February of 2010 (30\% approximately) respect to the previous year. However, the results from Table 3 indicate that the glacier slows down towards its terminal part and had, in the terminal portion, minor decelerating surface movement over the 2009-2014 period.

\section{Conclusions}

This paper shows the fruitful application of standard GNSS techniques applied to study the motion of debris-covered glaciers such as the HIG. The data acquisition of surface changes by semicontinuous GNSS survey stations was unique taking into account the implementation in a debris-covered glacier. Daily GNSS phase observations provided valuable information about the motion of the terminus of the HIG over the last five years, and were used to assess the changes in surface displacements and vertical position during the ablation seasons. The results demonstrate that it is possible to use L1 or L1, L2 GNSS receivers to acquire acceptable and reliable results in order to describe the movement of a glacier.

The lowermost portion of the HIG is entering a period of relative inactivity following recent rapid collapse, having recently experienced surface changes over several years (Fig. 6). Similar values of surface velocities were found at HIS1, HIS2 and HIS3 for the 2010-2014 period. The uppermost stations (HIS4 and HIS5), have also shown a major horizontal displacement during the 2013-2014 seasons, which may be related to the influence of an external source such as a rockglacier. Following these changes, velocities in elevation $\left(\mathrm{V}_{\mathrm{H}}\right)$ at the HIS1 site had a large motion rate in the 2009-2012 period, and a thinning increase in 2009-2010 that may be attributed to the low altitude reached by the glacier in 2006 (3,500 m a.s.1.), where the temperatures are above $0^{\circ} \mathrm{C}$, and the ice is prone to melt more quickly. The HIS5 station, in the 2013-2014 season, has the highest rate of elevation change in comparison with the others sites. Elevation changes rates of the GNSS surveys stations at the glacier show a similar variation that may attribute the area chosen for the present study is representative of the HIG.

On the other hand, the axial profiles surveyed between January 2012 and March 2013 provided complementary and continuous information on the HIG response, and allow the verification that the HIG is experimenting continuous ice degradation. The mean elevation velocity $\left(\mathrm{V}_{\mathrm{H}}\right)$ increased by $60 \%$ approximately from January 2012 to May 2013. Also, the results present here are consistent across all the studied locations, and comparable with other debris-covered glaciers in other regions such as the Himalaya and Karakorum taking into account specific characteristics like altitude, latitude and debris cover thickness.

We were unable to find a strong correlation between temperature and the ice melt rates in HIG; but in general terms, individual glaciers have their own response to climate, and may be influenced by a combination of others local factors. However, the increase in maximum values of the 2009-2014 summer seasons and the rise in the minimum values of 2009-2010 summer season do seem to agree with the increase of surface degradation in this period. 


\section{Acknowledgements}

The authors would like to thank A. Ferlito and A. Lo Vecchio for field assistance. S. Bonvalot IRD (Institute de Recherche pour le Développement, France) provided the PORT Station data. The meteorological data is courtesy of the General Irrigation Department of the Mendoza Government, and has records since 2000. The Mendoza Natural Resources Department provided support in the Aconcagua Park. D. Araneo and R. Villalba (IANIGLA) provided valuable comments. We also thank the two anonymous reviewers for their comments on the manuscript, and S. Key for his help in the English version. Fieldwork was funded by grant PICT 02220/07 Agencia Nacional de Ciencia y Tecnología Argentina (ANCyT) and "Sistema de Investigaciones Geodinámico Monte Aconcagua” Project (SIGMA).

\section{References}

Banerjee, A.; Shankar, R. 2013. On the response of Himalayan glaciers to climate change. Journal of Glaciology 59 (215): 480-490.

Benn, D.I.; Evans, D.J.A. 2007. Glaciers \& Glaciation. Hodder Arnold: 734 p. London.

Benn, D.I.; Evans, D.J.A. 2010. Glaciers \& Glaciation. Second edition. Hodder Education: 802 p. London.

Bown, F.; Rivera, A.; Acuña, C. 2008. Recent glacier variations at the Aconcagua basin central Chilean Andes. Annals of Glaciology 48: 43-48.

Copland, L.; Pope, S.; Bishop, M.P.; Shroder, J.F. Jr.; Clendon, P.; Bush, A.; Kamp, U.; Seong, Y.B.; Owen, L. 2009. Glacier velocities across the central Karakoram. Annals of Glaciology 50 (52): 41-49.

Dach, R.; Hugentobler, U.; Fridez, P.; Meindl, M. 2007. BERNESE GPS Software Version 5.0: User Manual. Astronomical Institute. University of Bern: 180-182. Berna.

Eiken, T.; Hagen, J.O.; Melvold, K. 1997. Kinematic GPS survey of geometry changes on Svalbard glaciers. Annals of Glaciology 24: 157-163.

Espizúa, L.; Bengochea, J. 1990. Surge of Grande del Nevado glacier (Mendoza, Argentina) in 1984: its evolution through satellite images. Geografiska Annaler 74A (3-4): 255-259.

Gómez-Tagle Chávez,A.; Chávez-Huerta, Y. 2004. Cálculo de la distribución espacial de la insolación potencial en el terreno empleando un MDE en un ambiente SIG. Investigaciones Geográficas, Boletín del Instituto de Geografía, Universidad Nacional Autónoma de México No. 55: 7-22.
Haeberli, W. 2005. Mountain glaciers in global climaterelate observing systems. Huber U.M., Global change and mountain regions (a state of the knowledge overview) (Burgmann, H.K.H.; Reasoner, M.A.; editors). Springer, Dordrecht: 169-175.

Hewitt, K. 1969. Glacier surges in the Karakoram Himalaya (Central Asia). Canadian Journal of Earth Sciences 6 (4) part 2: 1009-1018.

Intergovernmental Panel on Climate Change (IPCC). 2014. Climate Change 2014. Synthesis Report. (Pachauri, R.K.; Meyer, L.; editors): 151 p.

Kääb, A.; Huggel, C.; Fischer, L.; Guex, S.; Paul, F.; Roer, I.; Salzmann, N.; Schlaefli, S.; Schmutz, K.; Schneider, D.; Strozzi, T.; Weidmann, Y. 2005. Remote Sensing of glacier- and permafrost- related hazards in high mountains: an overview. Natural Hazards and Earth System Sciences 5: 527-554.

Kamb, B. 1985. Glacier Surge Mechanism: 1982-1983 Surge of Variegated Glacier, Alaska. Science 227: 469-479.

Kamb, B. 1987. Glacier Surge Mechanism Based on Linked Cavity Configuration of the Basal Water Conduit System. Journal Geophysical Research 92: 9083-9100.

Kotlyakov, V.M.; Rototaeva, O.V.; Desinov, L.V.; Osokin N.I. 2004. Causes and effects of a catastrophic surge of Kolka Glacier in the Central Caucasus. Zeitschrift für Gletscherkunde und Glazialgrologie 38 (2): 117-128.

Kotlyakov, V.M.; Osipova, G.V.; Tsvetkov, D.G. 2008. Monitoring surging glaciers of the Pamirs, Central Asia from space. Annals of Glaciology 48: 125-133.

Leiva, J.C. 2006. Assesment of Climate Change Impacts on the Water Resources at the Northern Oases of Mendoza Province, Argentine. Global Change in Mountain Regions (Price, M.; editor). Sapiens Publishing, Wiltshire 343: 81-83. Great Britain.

Leiva, J.C.; Cabrera, G.A.; Lenzano, L.E. 2007. 20 years of mass balance on the Piloto glacier, Las Cuevas river basin, Mendoza, Argentina. Global and Planetary Change 59: 10-16.

Lenzano, M.G.; Trombotto, D.; Leiva, J.C. 2012. Monitoreo de la superficie del Glaciar Horcones Inferior y sus termokarst, antes, durante el surge de 2003-2006. Andes Centrales Argentinos. Revista de la Asociación Argentina de Geofísicos y Geodestas (Geoacta) 37 (2): 1-4.

Lenzano, M.G. 2013. Assesment of ASTER DTM for glaciological applications in Central Andes. Mt. Aconcagua, Argentina. Journal of photogrammetry, remote sensing and geoinformation processing (PFG) 3: 197-208.

Lenzano, M.G.; Lenzano, L.; Trombotto, D.; Barón, J.; Lannutti, E. 2013. Applying GNSS and DTM tech- 
nologies to monitor the ice balance of the Horcones Inferior glacier, Aconcagua Region, Argentina. Journal of the Indian Society of Remote Sensing. doi: 10.1007/ s12524-013-0294-z.

Lidberg, M.; Johansson, J.M.; Scherneck, H.G.; Davis, J.L. 2006. An improved and extended GPS-derived $3 \mathrm{D}$ velocity field of the glacial isostatic adjustment (GIA) in Fennoscandia. Journal of Geodesy 81 (3): 1394-1432.

Mayer, C.; Lambrecht, A.; Mihalcea, C.; Belo, M.; Diolaiuti, G.; Smiraglia, C.; Bashir, F. 2010. Analysis of Glacial Meltwater in Bagrot Valley, Karakoram. Mountain Research and Development 30 (2): 169-177.

Meier, M.F.; Post, A.S. 1969. What are glacier surges? Canadian Journal of Earth Sciences 6 (807): 807-817.

Mihalcea, C.; Mayer, C.; Diolaiuti, G.; Lambrecht, A.; Smiraglia, C.; Tartari, G. 2006. Ice ablation and meteorological conditions on the debris-covered area of Baltoro glacier, Karakoram, Pakistan. Annals of Glaciology 43: 292-300.

Milana, J.P. 2007. A model of a Glaciar Horcones Inferior surge, Aconcagua region, Argentina. Journal of Glaciology 53 (183): 565-572.

Parry, M.; Canziani, O.; Palutikof, J.; Van der Linden, P.; Hanson, C. 2007. Climate Change 2007. Impacts, Adaptation and Vulnerability. Contribution of Working Group II to the Fourth Assessment Report of the Intergovernmental Panel on Climate Change, Published for the Intergovernmental Panel on Climate Change. Cambridge University Press: 937 p.

Sunil, P.S.; Reddy, C.D.; Ponraj, M.; Dhar, A.; Jayapaul, D. 2007. GPS determination of the velocity and strain-rate fields on Schirmacher Glacier, central Dronning Maud Land, Antarctica. Journal of Glaciology 53 (183): 558-564.

Tregoning, P.; Twilley, B.; Hendy, M.; Zwartz, D. 1999. Monitoring isostatic rebound in Antarctica with the use of continuous remote GPS observations. GPS Solutions 2: 70-75.

Unger, C.; Espizúa, L.E.; Bottero, R. 2001. Untersuchung von Gletscherständen im Tal des Río Mendoza (zentralargentinische Anden) Kartierung auf eines Surge-vorstosses des Horcones Inferior. Zeitschrift für Gletscherkunde und Glazialgeologie 36: 151-157.

Wang, Ch. 2003. Development of a low-cost GPS-based attitude determination system. MSc.Thesis (Unpublished). Department of Geomatics Engineering, Calgary: 178 p. Alberta.

Wang, P.; Li, Z.; Li, H.; Wang, W.: Wang, F. 2011. Ice Surface Elevation Change and Velocity of Qingbing$\tan$ Glacier No. 72 in the Tomor Region, Tianshan Mountains, Central Asia. Journal of Mountain Science 8: 855-864.

Wiśniewski, B.; Bruniecki, K.; Moszyński, M. 2013. Evaluation of RTKLIB's Positioning Accuracy Using low-cost GNSS Receiver and ASG-EUPOS. Transnav, The international Journal on Marine Navigation and Safety of Sea Transportation 7 (1): 79-85.

WGMS, (Espizúa). 2008. Fluctuations of Glaciers 20002005, Volume IX. Haeberli, (Haeberli, W.; Zemp, M.; Kääb, A.; Paul, F.; Hoelzle, M.; editors), ICSU (FAGS)/ IUGG (IACS)/UNEP/UNESCO/WMO, World Glacier Monitoring Service, Zurich, Switzerland.

Manuscript received: October 15, 2014; revised/accepted: October 19, 2015; available online: October 21, 2015. 